\title{
RELATIONSHIP OF CHARACTERISTICS OF COFFEE FARMERS DEVELOPMENT OF EYE FARMING GROUP TOWARDS PRODUCTION IN KEBAYAKAN SUB-DISTRICT CENTRAL ACEH DISTRICT
}

\author{
${ }^{1}$ Eliyin, ${ }^{2}$ Fitri Ilma \\ ${ }^{1}$ Study Program of Management Plantation Coffee, Faculty of Agriculture, University of Gajah Putih, Indonesia. \\ ${ }^{2}$ Study Program of Agribusiness, Faculty of Agriculture, University of Gajah Putih, Indonesia.
}

DOI: https://doi.org/10.51193/IJAER.2021.7204

\begin{abstract}
In Kebakat Subdistrict, many coffee farmers are coached in cultivating coffee plants, one of which is the Singah Mata Farmer Group which is fostered by the Kebakat District Agricultural Extension Agency, Central Aceh Regency. The characteristics of the coffee farmers studied were age, education level, number of dependents, length of farming and Landarea. The purpose of this study was to determine the relationship between the characteristics of Singah Mata coffee farmers and the production in Kebayaan Subdistrict, Central Aceh Regency. The data used are primary data with direct interviews with farmer observations using a questionnaire and using the Chi-square analysis method.

Based on the analysis obtained from the results of the research, the characteristics that are significantly related to production are the number of dependents with a significant value of 0.047 and land area with a significant value of 0.000 and characteristics that are not significantly related to production, namely age with a significant value of 0.183 , education level with a significant value of 0.285 , experience with a significant value of 0.218 . It is recommended that all members of the Singah farmer group who cultivate coffee in the Kebaya Subdistrict use family labor more efficiently in order to increase production in coffee farming and to the government to care more about the fostered farmers and continue to provide guidance and solutions and new information regarding farming activities.
\end{abstract}

Keywords: Characteristics, Coffee Farmers, Production 


\section{International Journal of Agriculture and Environmental Research}

ISSN: 2455-6939

Volume: 07, Issue: 02 "March-April 2021"

\section{INTRODUCTION}

The agricultural sector plays an important role and is a sector in the economy of developing countries, including Indonesia. The importance of agricultural sectors is shown by several factors, including the agricultural sector which can make a large contribution to the welfare of the Indonesian people.

Coffee is a plantation commodity that can significantly increase the level of commercial farmers and has a big prospect, especially at the present time where sub-sector commodity prices are experiencing encouraging developments (Retnandari and Tjokrominoto, 1991).

Aceh Tengah District is one of the coffee-producing districts which has the largest area of coffee planting and production, about 66 percent of the coffee area in Aceh Province. Coffee plants thrive due to the climate and natural conditions that support, this can be seen from the various potential natural resources such as horticultural crops, food crops and coffee plantations.

Success in coffee agribusiness requires the support of all parties involved in the production and marketing of coffee commodities, this is closely related to the characteristics of farmers who work on the coffee plant itself.

Keb Kebakaran is one of the districts that operates coffee gardens in Central Aceh, many farmers compress their land to grow coffee plants, even coffee plants are one of the livelihoods of the people in Kebayaan. In the Kebakat sub-district, farmers have farmer groups that are fostered by the Agricultural Extension Agency (BPP) and one of them is the Singah Mata farmer group located in Keb Kebayaan Sub-district, Central Aceh Regency. This is done to increase the production of coffee farmers.

In general, the Singah Mata farmer groups in the Kebayaan Subdistrict, Central Aceh Regency have different characteristics in coffee farming, ranging from age, education, number of dependents, farming experience, land area and so on. These characteristics are very influential in coffee farming, because the higher the age of the farmer, it is no longer productive to start farming.

\section{Identification}

Based on the background above, the problem that can be identified is whether there is a relationship between the characteristics of the coffee farmers who are members of the Singah Mata farmer group on the production in Keb Kebayaan District, Central Aceh Regency

\section{Research Objectives}




\section{International Journal of Agriculture and Environmental Research}

ISSN: 2455-6939

Volume: 07, Issue: 02 "March-April 2021"

Based on the background and problem identification above, the goal to be achieved is to determine the relationship between the characteristics of coffee farmers who are members of the Singah Mata farmer group on production in Keb Kebayaan Sub-district, Central Aceh Regency.

\section{Literature review}

\section{Development of Coffee}

Coffee is a type of plantation crop that has been cultivated for a long time and has a fairly high economic value. World coffee consumption reaches $70 \%$ from the Arabica coffee species and $26 \%$ from the robusta coffee species. Coffee comes from Africa, namely the mountainous regions of Etopia. However, coffee itself was only known by the world community after the plant was developed outside of its original area, namely Yemen in the southern part of Arabia, through Arab traders (Rahardjo, 2013).

In Indonesia coffee began to be known in 1696, which was brought by the VOC. The coffee plant in Indonesia began to be produced on the island of Java, and was only experimental, but because the results were satisfactory and was considered by the VOC to be quite profitable as a trading commodity, the VOC spread it to various regions so that the residents planted it (Najiyanti and Danarti, 2004).

\section{Definition of Characteristics}

Kamisa, (1997: 281) states that character is the psychological, moral or character traits that distinguish a person from others in character, character. Berkarekter means having character and having personality (http // pustaka. Pandani.web.id/2013/03/pengentuk-k Character.html).

According to (Ditjen Mandikdasmen - Ministry of National Education), Character is a way of thinking and behaving that characterizes each individual to live and work together, both within the sphere of family, society, nation and state. Individuals with good character are individuals who can make decisions and are ready to take responsibility for each consequence of the decisions they make (http // pustaka. Pandani.web.id/2013/03/pengentuk-k character.html).

\section{Characteristics of Farmers}

The characteristics of a farmer are the characteristics or traits possessed by a farmer that is displayed through the mindset, attitude pattern and action pattern towards his environment. The characteristics or traits possessed by farmers include several factorsor elements inherent in a person that can be said to be characteristics of farmers (Mislini, 2006 in Herman Sabagio) Farmers as farmers (both as farmers and as managers) are human beings who cannot always make decisions about their farming freely because of the limitations that exist on farmers. 


\section{International Journal of Agriculture and Environmental Research}

ISSN: 2455-6939

Volume: 07, Issue: 02 "March-April 2021"

Characteristics of farmers include age, education, experience, number of dependents, land area (http.blog.diamas.com/2013.html).

\section{a. Age}

A person's age determines the work performance or performance of that person. The heavier the work physically, the older the workforce, the lower the performance will be (Ken Suratiyah, 2009).

Age of farmers will affect their physical abilities and responses to new things inrunning their farms. According to Kartasapoetra (1991), elderly farmers will find it difficult to be given insights that can change the way they think, work, and live. Age of farmers will affect their physical abilities and responses to new things in running their farms. (Ir. Sutarto, M.Si: 2008).

Farmers who are getting older, considerations and decisions are relatively long compared to young farmers (Fadholi Hermanto: 1996).

\section{b. Level of education}

The higher the education, he will be careful and calculate the possible risks faced (Fadholi Hermanto: 1996)

Mardikanto (1993) explains that education is a reciprocal process of every human person in his adjustment to nature, friends, and the universe. Education can be obtained through formal and non-formal education. The level of education of farmers, both formal and non-formal, will affect the way of thinking that is applied to their business, namely in business rationalization and the ability to take advantage of every opportunity that exists. (Ir. Sutarto, M.Si: 2008).

Education takes another advantage insofar as the experience will help people move forward the desired development (Hassan Su'ud: 2004).

\section{c. Experience (Length of Trying)}

Faming experience in general can improve skills and increase farmers' knowledge, especially in the field of seaweed. Farmers who have a lot of experience are usually very careful in adopting a new innovation than farmers who still have little experience (Hermanto, F, 1996).

\section{d. The number of dependents}

The number of family dependents who are of productive age is one of the important human resources in farming activities. while productive family members are a burden on the family which causes a lack of income (Damsar, 2007). 


\section{e. Land area}

From an efficiency point of view, the more land is cultivated, the higher the production and income per unit area (Ken Suratiyah: 2006).

As an economic source for rural communities, especially farmers, the area of agricultural land greatly determines the production and household income of farmers (Mardikanto: 1994).

\section{Production}

Production is a process of utilizing available resources, by which it is hoped that more results will be realized than all the sacrifices that have been given (Kartasapoetra: 1996) Production is the technological relationship between the maximum amount of output that can be produced by each and each input device (factors of production). (PaulA.Samuelson: 1992).

\section{Chi-square analysis}

Chi-square is a statistical analysis technique to determine the significant difference between the proportion (and / or probability) of the subject or object of research that is categorized. Chisquare is used as a research hypothesis testing tool to test related samples, the related sample here is one research sample that is subjected to two kinds of treatments, which are then seen for changes (Soepeno, 2002).

Chi-Square Characteristics:

- Chi-square values are always positive

- There are several Chi-Square distributions, namely the Chi-Square distribution with DK $=1,2,3$ etc.

- The form of the Chi-Square distribution is sticking out positively

\section{Hypothesis}

Based on the background and problem identification, it can be hypothesized that there is a relationship between characteristics (age, education, land area, number of dependents, experience, and coffee production in Keb Kebayaan Subdistrict, AcehTengah Regency.

\section{RESEARCH METHOD}

\section{Place and Time of Research}

This research was conducted in Keb Kebayaan Subdistrict, Aceh Tengah District, where the location was determined deliberately (purposive sampling) with the consideration that the area 
has a lot of potential and the community is working on the cultivation of coffee plants and it is necessary to examine the influence of the characteristics of coffee farmers assisted by Singah Mata farmer groups on production in the area. Keb Kebayaan sub- district, Central Aceh Regency.

This research was conducted from January 2014 to completion which took place in the research area, namely Keb Kebayaan Subdistrict, Central Aceh Regency.

\section{Sample Determination Method}

The sampling method used in this study is saturated sampling, namely the sampling technique when all populations are used as samples and it is also known as a census (Riduwan and Akdon: 2010).

Population is the totality of all possible values, either the results of counting or quantitative or qualitative measurements on certain characteristics regarding a complete set of objects (Nawawi: 2003 in Riduwan and Akdon).

The population in this study were all of the Singah Mata farmer groups in Bukit Sama Village in Kebayaan District, Central Aceh Regency, as many as 34 farmers.

The sample size used was as much as 34 farmers in the Singah Mata farmer group.

\section{Data Collection Methods}

The data collection methods used in this research are:

\section{a. Observation (observation)}

Observation or observation is a way of collecting data by going in and seeing directly the field (laboratory), of the object under study.

\section{b. Literature research}

Literature search is a way of collecting data using literature search is a way of collecting data using literature search is a way of collecting data using part or all of existing data or data reports from previous researchers. Literature research is also called indirect observation (Iqbal Hasan, M.M.:2009)

\section{Use of questionnaires (questionnaires)}

The use of a questionnaire is a way of collecting data using a list of questions (questionnaire) or a questionnaire for the object under study (population). (Iqbal Hasan, M.M.:2009) 


\section{Interview (interview)}

Interviews are a way of collecting data by directly holding questions and answers to the object under study or to intermediaries who know the problem of the object being studied. (Iqbal Hasan, M.M.:2009)

\section{Data Analysis Methods}

To determine the effect of coffee farming characteristics on farmers' land ownershipusing the chi-square formula as follows:

$$
X^{2}=\sum_{i=1}^{k} \frac{\left(O_{1}-E_{1}\right)^{2}}{E_{1}}
$$

Where:

$\mathrm{X}=$ Chi-square value (if positive, there is a relationship between farmer characteristics and production)

$\mathrm{O}=$ observed frequency

$\mathrm{E}=$ the expected frequency of the category

$\mathrm{K}=$ Number of categories

Krateria Decisions:

1. If the price of Chi Square $(\mathrm{X} 2) \geq$ Chi Square Table è Zero Hypothesis (H0) is rejected \& Alternative Hypothesis (Ha) is accepted.

2. If the price of Chi Square (X2) <Chi Square Table è Zero Hypothesis (H0) is accepted \& Alternative Hypothesis (Ha) is rejected.

\section{RESEARCH RESULTS AND DISCUSSION}

\section{Characteristics of Sample Farmers}

To get an overview of the condition of the respondents studied, it is necessary to state the characteristics of the sample farmers including age, education, number of dependents, experience, and land area.

\section{a. Age Level}


Age level is the age ratio of a person, especially the farm manager, the age ratio of the farmer is very influential on the area of his cultivated land, the older the farmer is or the age of the farmer, the less land area he can cultivate. To find out the age of the sample farmers can be seen in the table below:

Table 1: Average age levels of coffee farmers who are members of the Singah Mata farmer group in Keb Kebayaan Sub-district, Central Aceh District.

\begin{tabular}{|c|c|c|c|}
\hline No & Age Level & Number & of Percentage \\
\hline & & Samples & $(\%)$ \\
\hline 1 & $25-39$ & 6 & 17,65 \\
\hline 2 & $40-54$ & 15 & 44,12 \\
\hline 3 & $55-69$ & 13 & 38,24 \\
\hline
\end{tabular}

Source: Primary Data Processed, 2019

Based on the data in the table above, it can be seen that the number of samples aged 25-39 years is 6 people, the number of samples aged 40-54 years is 15 people, and samples aged 55-69 years are 13 samples. The most densely populated sample was at the age of 40-54 years, amounting to 15 people.

\section{b. Relationship between Age and Production}

Age level is the ratio of a person, especially the farm manager, to determine the relationship between age and solid coffee production, see the table below.

Table 2: The relationship between the age of the Singah Mata farmer group and coffee production in the Kebayaan sub-district.

\begin{tabular}{llllll}
\hline No & $\begin{array}{l}\text { Stratum } \\
\text { Produksi } \\
(\mathrm{Kg})\end{array}$ & $\begin{array}{l}25-35 \text { year } \\
(\%)\end{array}$ & $\begin{array}{l}40-54 \text { year } \\
(\%)\end{array}$ & $\begin{array}{c}55-69 \text { year } \\
(\%)\end{array}$ & amount \\
\hline 1 & $240-1346$ & $23,5 \%$ & $41,2 \%$ & $35,3 \%$ & $100 \%$ \\
2 & $1347-2453$ & $14,3 \%$ & $57,1 \%$ & $28,6 \%$ & $100 \%$ \\
3 & $2454-3560$ & $0 \%$ & $0 \%$ & $100 \%$ & $100 \%$ \\
\hline
\end{tabular}

Source: Primary Data Analysis

From Table 2 above, it can be seen that the level of production is the highest (2454-3560), namely at the age of 55-69 years, while the production is moderate, namely at the age of 40-54 years, and the production is low, namely at the age of 40-54 years as well. 


\section{c. Level of education}

The level of education in the sample referred to in this research is measured based on the level of formal education that has been attended. The education level is divided into three categories, namely SD, SMP, SMA. And complete data on the level of education of sample farmers are presented in table 10 below.

Table 3: The average level of education of the Singah Mata farmer groups in the Kebayaan sub-district

\begin{tabular}{llll}
\hline No & Level of education & Number of Samples & $\begin{array}{l}\text { Percentage } \\
(\mathbf{\%})\end{array}$ \\
\hline 1 & primary school & 16 & 47,06 \\
2 & Junior high school & 10 & 29,41 \\
3 & Senior High School & 8 & 23,53 \\
\hline amount & & 34 & 100 \\
\hline
\end{tabular}

Source: Primary Data Processed, 2019

Based on the data above, it can be seen that the average respondent is only educated at the elementary level (SD), namely as many as 16 people, as many as 10 people at the junior high school level, and 8 people at the high school level. It can be concluded that the sample farmers have more elementary school education (SD).

\section{d. The Relationship of Education to Production}

The level of education possessed by farmers will show the level of intelligence related to one's thinking power. To find out the relationship between education level and coffee production, it can be seen in the table below.

Table 4: The relationship between Singah Mata farmer education and coffee production in Keb Kebayaan sub-district.

\begin{tabular}{llllll}
\hline No & $\begin{array}{l}\text { Stratum } \\
\text { Produksi } \\
(\mathrm{Kg})\end{array}$ & $\begin{array}{l}\text { primary } \\
\text { school (\%) }\end{array}$ & $\begin{array}{l}\text { Junior } \\
\text { school (\%) }\end{array}$ & $\begin{array}{l}\text { Senior } \\
\text { School (\%) }\end{array}$ & amount \\
\hline 1 & $240-1346$ & $58,8 \%$ & $23,5 \%$ & $17,6 \%$ & $100 \%$ \\
2 & $1347-2453$ & $42,9 \%$ & $35,7 \%$ & $21,4 \%$ & $100 \%$ \\
3 & $2454-3560$ & $0,0 \%$ & $33,3 \%$ & $66,7 \%$ & $100 \%$
\end{tabular}

Source: Primary Data Analysis 
From table 11 above, we can see that the highest production is farmers with high school education, moderate production is found in farmers with elementary education, and thelowest production is also farmers with elementary education.

\section{e. The number of dependents}

The family dependents referred to here are all people who live in the same house or who are outside and become the responsibility of the head of the family, which includes his wife, children, and other family members who are hitching a ride.

Family members can be used as labor in land management activities so that they can get more results.

The sample classification based on the number of family dependents can be seen in table 12 , as follows.

Table 5: Average number of dependents of coffee farmers in the study area

\begin{tabular}{lllll}
\hline \multicolumn{2}{c}{ No } & \multicolumn{1}{c}{$\begin{array}{c}\text { The number of } \\
\text { dependents }\end{array}$} & Number of Samples & Percentage (\%) \\
\cline { 2 - 3 } 1 & $1-2$ people & 12 & 35,29 \\
2 & $3-4$ people & 7 & 20,59 \\
3 & $5-6$ people & 15 & 44,12 \\
\hline amount & & 34 & 100
\end{tabular}

Source: Primary data sources were processed, 2019

Based on the table above, the average number of dependents of the coffee farmer group in the study area which has 1-2 dependents is 11 people, the number of dependents is 3-4 people as many as 16 people, and the number of dependents from 5-6 people is 7 people.

With the large number of family dependents it can spur farmers to increase productivity and the results of farming on the land they finance.

\section{f. The relationship between the number of dependents and production}

The number of dependents owned by the farmer will show the level of success of the farmer, to find out the relationship between the number of dependents on rice production can be seen in the table below. 
Table 6: The relationship between the number of dependents of the Singah Mata farmer group and coffee production in the Kebayaan sub-district in 2014

\begin{tabular}{lllcrc}
\hline No & Stratum & 1-2 soul & $3-4$ soul & $5-6$ soul & amount \\
\cline { 2 - 6 } 1 & $240-1346$ & $23,5 \%$ & $35,3 \%$ & $41,2 \%$ & $100 \%$ \\
2 & $1347-2453$ & $57,1 \%$ & $7,1 \%$ & $35,7 \%$ & $100 \%$ \\
3 & $2454-3560$ & $0 \%$ & 0 & $100 \%$ & $100 \%$ \\
\hline
\end{tabular}

Source: Primary Data Analysis

From the table above, we can see that the highest production is the number of dependents 5-6 and moderate production is the number of dependents 3-4 people, and the lowest productionis the number of dependents 5-6 people too.

\section{g. Business Experience}

Farming experience will affect the skill level of farmers in managing their farms, detailscan be seen in the table below

Table 7: Average length of farming for coffee farmers of members of the Singah Mata farmer group in Keb Kebayaan subdistrict, 2019

\begin{tabular}{llll}
\hline No & $\begin{array}{l}\text { The duration of trying } \\
\text { (year) }\end{array}$ & $\begin{array}{l}\text { Number of samples } \\
\text { (people) }\end{array}$ & Persentage (\%) \\
\hline 1 & $3-15$ people & 15 & 44,12 \\
2 & $16-28$ people & 14 & 41,18 \\
3 & 29-41 people & 5 & 14,70 \\
\hline \multicolumn{2}{l}{ amount } & 34 & 100 \\
\hline
\end{tabular}

Source: Primary data processed in 2019

Based on the table above, it can be seen that the length of time for farmers to farm is between 115 years as many as 12 people, farmer experience between 16-28 years is 7 people, farmer experience is $29-41$ years as many as 15 people.

\section{h. The Relationship Between Old Tried Against Production}

The length of time he has worked with farmers will show the farmer's level of experience. Farming experience will affect the skill level of farmers in managing their farming, to find out the old relationship between farming and coffee production can be seen in table 15 below. 
International Journal of Agriculture and Environmental Research

ISSN: 2455-6939

Volume: 07, Issue: 02 "March-April 2021"

Table 8: The relationship between Singah Mata farmer group coffee production and experience / duration of working in the Kebayaan sub-district in 2014

\begin{tabular}{llllll}
\hline No & $\begin{array}{l}\text { Stratum } \\
\text { Produksi(Kg) }\end{array}$ & 3-15 year & 16-28 year & 29-41 year & Amount \\
\hline 1 & $240-1346$ & $29,4 \%$ & $17,6 \%$ & $52,9 \%$ & $100 \%$ \\
2 & $1347-2453$ & $57,1 \%$ & $28,6 \%$ & $14,3 \%$ & $100 \%$ \\
3 & $2454-3560$ & $33,3 \%$ & $33,3 \%$ & $33,3 \%$ & $100 \%$ \\
\hline
\end{tabular}

Source: Primary Data Analysis 2019

From the table above we can see that the most moderate production is production at 3-15 years experience, the lowest production is at 29-41 years experience.

\section{i. Land area}

The area of land for coffee farmers in the Kebayaan sub-district is very different. Coffee farmers in the sub-districts calculate the area of land depending on the number of coffee plants planted, here we can see the area of the farmer's land in the table below.

Table 9: Average area of land used by coffee farmers in Kebayaan sub-district, Central Acehdistrict.

\begin{tabular}{llll}
\hline N0 & Land area (Ha) & Number of sample & Percentage (\%) \\
\hline 1 & $0,25-1,166$ & 17 & 50.00 \\
2 & $1,167-2,083$ & 14 & 41.18 \\
3 & $2,084-3,000$ & 3 & 8.82 \\
\hline & amount & 34 & 100 \\
\hline
\end{tabular}

Source: primary data processed in 2019

From the table above, we can see that there are 17 farmers who have a land area of 0.25 1.166 hectares, 3 people who have a land area of 1.167-2.083 hectares, and 3 people who have a land area of 2.084-3.00 hectares.

\section{j. The Relationship Between Land Area and Production}

The area of land owned by the farmer will show the level of production of the farmer, tofind out the old relationship with coffee production can be seen in table 17. 
International Journal of Agriculture and Environmental Research

ISSN: 2455-6939

Volume: 07, Issue: 02 "March-April 2021"

Table 10: The Relationship of Production to the Land Area in the Kebayaan Subdistrict, 2014

\begin{tabular}{clllll}
\hline No & $\begin{array}{l}\text { Stratum } \\
\text { Produksi }(\mathrm{Kg})\end{array}$ & $\begin{array}{l}0,25-1,166 \\
(\mathrm{Ha} \%)\end{array}$ & $\begin{array}{l}1,166-2,083 \\
(\mathrm{Ha} \%)\end{array}$ & $\begin{array}{l}2,084-3,000 \\
(\mathrm{Ha} \%)\end{array}$ & Amount \\
\hline 1 & $240-1346$ & $94,1 \%$ & $5,9 \%$ & $0,0 \%$ & $100 \%$ \\
2 & $1347-2453$ & $7,1 \%$ & $85,7 \%$ & $7,1 \%$ & $100 \%$ \\
3 & $2454-3560$ & $0,0 \%$ & $0,0 \%$ & $100 \%$ & $100 \%$ \\
\hline
\end{tabular}

Source: Primary Data Analysis 2019

From the table above, we can see that the highest production is on land area of $2.084-3.000 \mathrm{Ha}$, moderate production is on land area of $1.166-2.083 \mathrm{Ha}$, while the lowest production is on land area of 0.25-1.166 Ha.

2. Analysis of the Relationship between Farmers' Characteristics and Coffee Production inthe Kebayaan District

Analysis of the relationship between the characteristics of coffee farmers and production which includes age, education, number of dependents, experience, and land area. Namely the analysis using SPSS and the results of the analysis can be seen in Table 18 below.

Table 11: The results of the analysis using Spss between the characteristics of the Singah Mata farmer group and production.

\begin{tabular}{lll}
\hline No & Uraian & Asymp sig (2-sided) \\
\hline 1 & Age & 0,183 \\
2 & Education & 0,285 \\
3 & The number of dependents & 0,047 \\
4 & Long trying / experience & 0,218 \\
5 & Land area & 0,000 \\
\hline
\end{tabular}

Source: Primary Data Analysis 2019

\section{a. Age}

From the table above we can see that the results of the analysis using the Chi-square are 6.22. With a significant value of 0.183 . The significant value is greater than 0.05 , so it can be concluded that acceptance is rejected, meaning that there is no relationship between age and coffee production. 


\section{International Journal of Agriculture and Environmental Research}

ISSN: 2455-6939

Volume: 07, Issue: 02 "March-April 2021"

So according to the results of the research, age level is not a reference for farmerswho cultivate coffee, because in Kebayaan sub-district the farmers who cultivate are quite old, this is not the same as tiori (Kensuratiyah) that the higher the age of the farmer, the less capable land is. worked on.

In the Kebayaan sub-district that grows coffee plants is a family farm in which the parents are the owners of the farming land, but the ones who cultivate or do the farming are family members, which causes no relationship between age and coffee production in Kebayaan District.

\section{b. Education}

From the table above we can see that the results of the analysis using the chi-square. The chisquare value is 5.02 . With a significant value of 0.285 . The significant value is greater than 0.05 , so it can be concluded that acceptance is rejected, meaning that there is no relationship between education and coffee production.

According to theory (Ken Suratiyah) states that education will affect production and income.

Meanwhile, the educational level of the research location does not become an important benchmark in cultivating coffee, meaning that farmers do not have to have special education to do coffee farming, but farmers just need to see from other farmers and they can immediately imitate the methods of how to cultivate coffee.

\section{c. The number of dependents}

From the table above, we can see that the results of the analysis using the Chi-Square are 9.63. With a significant value of 0.047 , a significant value less than 0.05 , thus it can be concluded that rejected and accepted, meaning that there is a relationship between the number of dependents and coffee production.

So according to the results of the study there is a relationship between the number of dependents on coffee production, in theory (Damsar: 2007) states that the number of dependents who are at productive age is one of the important human resources in farming activities. it is clear because the more the number of family dependents, the less absorbing labor from outside the family, so that it does not cost much in processing.

\section{d. Experience (long time in dealing with)}

From the table above we can see that the results of the analysis using the chi-square. The Chisquare value is 5.26. And the significant value is 0.218 . The significant valueis greater than 0.05 , 
so it can be concluded that it is accepted, it means that there is no relationship between the length of dealing with coffee production.

In theory (Hermanto: 1996) states that farmers who have a lot of experience are usually very careful in adopting a new innovation compared to farmers who still have little experience.

\section{e. Land area}

From the table above we can see that the results of the analysis using the chi-square. Chi-square value is 38.11 with a significant value of 0.000 . A significant value is smaller than 0.05 , it can be concluded that rejected is accepted, meaning that there is a relationship between land area and coffee production.

So it is clear that there is a relationship between land area and production, because themore land is used, the higher the production produced. In theory (Hermanto, 1993) itis also stated that the more land is cultivated, the higher the production and incomeper unit.

\section{CONCLUSIONS AND SUGGESTIONS}

\section{A. Conclusion}

Characteristics that are significantly related are:

1. Land area with a significant value of (0.000). The significance value is smaller than. rejected and accepted means that there is a relationship between age and production.

2. Number of dependents with a significant value (0.047). The significance value is smaller than. Rejected and accepted means that there is a relationship between the number of dependents and production.

3. Characteristics that are not significantly related, namely

4. Age significant value (0.183). The value is significantly greater than. accepted and rejected means that there is no significant relationship between age and production.

5. Education significant value (0.285). The value is significantly greater than. accepted and rejected means that there is no significant relationship between education and production.

6. Long time to cultivate significant value (0.218). The value is significantly greater than. Accepted and rejected means that there is no significant relationship between duration and production. 


\section{BIBLIOGRAPHY}

Anonymous. Bercocok Tanam kopi, Kasanius, 1982 Abbas.T. Ilmu Usahatani, Penebar Swadaya, Jakarta, 1983

Cahyono, Andy. Karakteristik Sosial Ekonomi Yang Mempengaruhi Pendapatan RumahTangga Penyadap Getah Pinus Di Desa Somagede, Kabumen, Jawa Tengah.

Damsar. Sosiologi Ekonomi, Rajawali Pers. Jakarta,2007

Hisaini, Muhammad. Karakteristik Sosial Ekonomi Rumah Tangga Dan Tingkat Ketahanan Pangan Rumah Tangga Petani Di Kabupaten Barito Kuala, Jurnal. Fakultas Pertanian Universitas Lambung Mangkurat, 2012

Hermanto, Fadhholi. Ilmu Usahatani. Penebar Swadaya. Jakarta, 1996 Ikbal, hasan. PokokPokok Materi Stasistik. bumi Aksara, 2003

Kartasa, Poetra, Pengantar Ekonomi Produksi Pertanian. Bumi Aksar, Jakarta,1987

Mintarti. Karakteristik Masyarakat Tani Padi Sawah: Suatu Studi Tentang Petani Tangguh (Studi Kasus Di Desa Karyamulya, Kecamatan Batujaya, Kerawang), Jurnal. Institut Pertanian Bogor, 1990.

Rahardjo, Pudji. Kopi. Penebar Swadaya, Jakarta, 2013

Suratiyah, Ken. Ilmu Usaha Tani. Penebar Swadaya, Jakarta,2009. Soepeno, Bambang. Statistik Terapan. Rineka Cipta, Jakarta, 2002

Sri Najiyati dan Danarti. Kopi Budidaya dan Pasca Panen, Swadaya. Jakarta,2008

Su'ud Hasan. Pengenalan Pembangunan Dan Keterkaitannya. KDT. Banda Aceh, 2004 Sutarso. Hubungan Sosial Ekonomi Petani Dengan Tingkat Adopsi Inovasi Tehnologi

Komoditas Jagung Di Sidoharjo Wonogiri, 2008

Rukka, Hermaya. Hubungan Karakteristik Petani Dengan Respon Petani Terhadap Penggunaan Pupuk Organik Pada Padi Sawah, Jurnal. Sekolah Tinggi Penyuluhan Pertanian Gowa, 2006

Paul A. Samuelson, William D. Nordhaus. Ekonomi. Erlangga. Jakarta, 1992 http//pustaka. Pandani. web.id/2013/03/pengertian-karakter.html 
International Journal of Agriculture and Environmental Research

ISSN: 2455-6939

Volume: 07, Issue: 02 "March-April 2021"

hhtp://tugasski.blogspot.com/2013/04/pengertian-karateristik.html.

http://blog.diamas.com/2013.htm 